\title{
Introduced marine organisms in China from Japan and their impacts
}

\author{
Xuezheng LIN ${ }^{1,2 *}$ AND Xiaohang HUANG ${ }^{1,2}$ \\ ${ }^{1}$ Key Lab of Bioactive Substances, SOA, Qingdao 266061, ${ }^{2}$ First Institute of Oceanography, SOA, Qingdao \\ 266061, China
}

\section{Introduction}

The introduction of marine organisms is one of the key global environmental issues today. It has been drawing broad attention among marine ecologists. The marine invasive species has been regarded as a major threat to marine biodiversity and a contributor to environmental changes. It is recognized that the problem of marine invasive species is getting worse globally with the progressively global trade and communication. Considering both the mode of entry and the extent of the impacts of an alien species in new environments, many species present a regional and global problem which needs collaborated solutions at regional and global level. A set of key terms have already been proposed as an operative tool for marine scientists. ${ }^{1,2)}$ The terms of biological pollutants and biological pollution have been used to discuss the problems caused by invasive species, and their definitions and concepts used in assessing and managing marine pollution are still in discussion. ${ }^{3)}$ Many species of marine alien organisms have been introduced into China, either by intentional introduction for aquaculture and planting based on their economic, ecological and social significances, or by introduction of unconscious activities such as casual import and discharge of ballast water, etc.

The majority of introduction is due to human activities, particularly trade, transport and travel. It has been widely perceived that the littoral biota in many regions had undergone rapid and profound changes caused by exotic species. State Oceanic Administration of P.R. China has investigated the status of marine invasive species in 2006. The data analysis revealed that about 30 species were introduced into China for mariculture or trial mariculture. Approximately 100 ornamental species were introduced into aquarium in countrywide.

\section{Introduced marine species in China from Japan}

Based on the research program of Ministry of Science and Technology, P.R. China (2004DIB3J085), more than 150 marine alien species have been identified (http: //bioinvasion.fio.org.cn), including more than 20 species of seashell, 20 species of algae, 3 species of halophyte, 8 species of shrimp, and more than 60 species of fish. Since Japan is one of the nearest neighbors of China, many marine species have been introduced from Japan recorded from last century. Preliminary investigation showed that more than 14 species have been introduced from Japan and they are listed as follows: Patinopecten yessoensis, Fugu rubripes, Laminaria longissima Mijabe, Laminaria Japonica, Verasper moseri Jordan et Gilbe, Anguilla japonicus, Haliotis madaka, Haliotis discus hannai, Penaeus (Marsupenaeus) japonicus Bate, Crassostrea gigas, Undaria pinnatifida, Strongylocentrotus intermedius, Eucheuma amakusaensis, Desmarestia ligulata. ${ }^{4-8)}$

There is no lack of examples of successful introduction like Laminaria Japonica which has become the dominant mariculture species in China since the early decade of last century. A new species of abalone, designated as No. 1 Dalian, was a hybrid after a deliberated endeavor of cross-fertilization between Haliotis discus Iwate population and Dalian population by Chinese scientists. The hybrid showed distinct advantages like wide adaptability, high survival rate and rapid growth, and its output occupies $90 \%$ of annual abalone production. To maintain the fine seed for seaweed mariculture, some species like Undaria pinnatifida is keeping introduction from Japan every year.

\section{Potential impacts of introduced species}

As the rate of initiative introduction of marine alien species is accelerating in recent years without elaborate ecological and economic cost-benefit assessment, some

*Tel : 86-532-8896-7422. Fax : 86-532-8896-9292. Email : linxz@fio.org.cn 
exotic species have been brought to bear certain impacts to native diversity on a native scale, as well as contributing to the regional "homogenization" of marine biodiversity. Some negative impacts are being appeared which are even threatening human health and reversing economic activities of the native fisheries, aquaculture, tourism and marine infrastructure. Firstly, alien species compete with native species, which may result in destruction of ecological balance in native niche. Secondly, alien species can bring about genetic pollution through their hybridization with native species. Thirdly, pathogenic organism may be imported unconsciously and imperil native species. Fourthly, many species of harmful alga bloom are believed to have been introduced by ship ballast water and are considered to be responsible for the ecological disaster. ${ }^{5,9)}$ Fifthly, even positively introduced species like Laminaria japonica and Undaria pinnatifida have no evaluation on their negative impacts on indigenous species and biodiversity in culture area.

Strongylocentrotus intermedius, an native species in Hokkaido of Japan, feeds chiefly on benthic kelp. Since its introduction into Dalian, the nearest area from Japan, in 1989 and due to lack of effective management, it often compete food and ecological niche with native species Strongylocentrotus nudus while it escapes from the fishery farm. It propagates in the natural ecosystem and might cause destructive damage to the native sea urchin. Under its influence, native benthic algae community has also been altered.5,6)

Desmarestia ligulata, an native species in Japan, might be unintentionally introduced into Dalian area along with introduction of Undaria pinnatifida from Japan served as the seed every year. After settlement in China, the average frond length of D. ligulata grown in China is as long as $1 \mathrm{~m}$, which is much longer that of $D$. ligulata grown in Japan (the average frond algae is $30 \mathrm{~cm} \sim 50$ $\mathrm{cm})$. Mass propagation of this species can bring about great effects on the native inshore fisheries and even affects the native tourism because it secretes sulphuric acid after its death and results in the deterioration of ambient seawater quality. 5,6 )

In the natural marine environments in North of China, alien Patinopecten yessoensis and indigenous species Chlamys farreri might hybridize because of their overlapping idiophase. The idiophase of $P$. yessoensis is from February to April and that of indigenous $C$. farreri is from April to June. Moreover, P. yessoensis and C. farreri have been hybridized in laboratory successfully. If the hybrid species survives and propagates in the natural conditions, it will inevitably cause genetic pollution to the indigenous species. ${ }^{5,10)}$

\section{Management and control}

The problem of marine alien organisms, especially invasive species is getting worse with the growing environmental, social and economic risks in recent years. Its negative impacts on people's health and loss of net socioeconomic benefits is still be ignored by administrations and environmental interest groups. Marine invasive species present a regional and global problem that requires regional and global solutions. Solutions will need to address environmental impacts and net socioeconomic benefits based on regional differences in perspectives, technical capacity and financial resources. ${ }^{1)}$ Like many of other environmental consequences of globalization, biological invasions require that decisions be taken under uncertainty, decision-maker in such circumstances has to choose between main strategies: mitigation and adaptation. ${ }^{11)}$

There are still no special law and statute on introduction and management of marine alien organisms in China for little cognition to their impacts, especially on native ecosystem. The main concern on alien species is its economic value. The constitution of actual laws and by laws focus on human health and safety of agriculture, and there are no mature consideration for impacts of alien species on biodiversity and ecological damage. ${ }^{7)}$

A management system is required to assess the risks of marine alien species invasion, and then to determine appropriate legislation and law enforcement actions. The design of policy should emphasize the following six points in the generic process of this issue: prevention, detection, quarantine, control, mitigation or eradication. Before an alien species is introduced, it is necessary to determine the risk of introduction, establishment and spread of marine species in the particular regions, and their potential impacts on the native species diversity and the health of ecosystem, as well as human health and economic activities. Successful mitigation and management of these threats by marine invasive species will be possible only based on a general evaluation of the risks. More and more attentions are being paid to the marine alien species invasion in China. Research works have been undergoing and several statutes on introduction of alien species have been enacting. 


\section{References}

1) Nicholas B, Angela W, Max A. Marine invasive alien species: a threat to global biodiversity. Marine Policy 2003; 27: 313-323.

2) Occhipinti-Ambrogi A, Galli BS. A uniform terminology on bioinvasions: a chimera or an operative tool? Mar. Poll. Bull. 2004; 49: 688-694.

3) Elliott M. Biological pollutants and biological pollutionan increasing cause for concern. Mar. Poll. Bull. 2003; 46: 275-280.

4) Liu SL, Dong YQ. A study on present status and development strategy of fine species introduction for aquaculture in Qingdao. J Ocean. of Huanghai \& Bohai Seas (in Chinese) 2000; 18: 93-99.

5) Liang YB, Wang B. Alien marine species and their impacts in China. Biodiv. Sci. (in Chinese). 2001; 9: 458-
465.

6) Zhao SJ, Zhu AY, Zhang XJ. Alien marine species and their management in China. Ocean Exploit. Managm. (in Chinese) 2005; (3): 58-66.

7) Zhao SJ, Zhang XJ, Li CD, et al. Alien fishes of mariculture in China. Mar. Sci. (in Chinese) 2006; 30: 75-80.

8) Liu SL, Wang FQ, Yang M, et al. Investigation and study on the aliem species in aquaculture in Shandong Province. Mar. fish. Res. (in Chinese) 2003; 24: 66-71.

9) Lin XZ, Wang NF, Chen KS. Alien Marine species and their ecological impacts in China. Advances in Mar. Sci. (in Chinese) 2005; 23 (suppl.) : 110-116.

10) Liu XX, Liang YB. Alien marine species invasion and their ecological damage. $D a Z i$ Ran (in Chinese) 2004; (2): 54-56.

11) Perrings C. Mitigation and adaptation strategies for the control of biological invasions. Ecol. Econom. 2005; 52: 315-325.

〈和文要約〉

日本から中国に導入された海洋生物とその影響

海面養殖の拡大により, 多くの海産外来種が，社会経 済あるいは生態系への影響を検討されることなく中国国 内に持ち込まれている。そのうち, 養殖用として 14 種 を超える生物が日本から導入され, それらの大部分は現 在では中国国内で定着していると考えられている。しか し, それらが中国の海洋生態系の多様性や在来種の生存
に及ぼす影響についての知見は少ない。そのため，様々 な外来種, とりわけ, 今後導入される可能性があるかあ るいは分布域を拡大する恐れのある外来種に関してのリ スク評価並びに管理体制が求められている。 （浜口昌巳 訳） 